\section{BIOLOGICAL MATURATION AND MUSCULAR STRENGTH: MEDIATION ANALYSIS IN PREPUBESCENT GIRLS}

\author{
MATURAÇÃO BIOLÓGICA EFORÇA MUSCULAR: ANÁLISE DEMEDIAÇÃO EM MENINAS PRÉ-PÚBERES
}

MADURACIÓN BIOLÓGICA Y FUERZA MUSCULAR: ANÁLISIS DE MEDIACIÓN EN NIÑ̃S PREPUUBERES

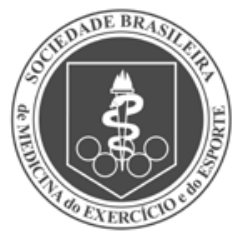

Original Article ARtigo Original Artículo Original

\begin{abstract}
Leonardo Gomes de Oliveira Luz ${ }^{1,2}$ (Physical Education Professional)

Tatiana Durão D’Ávila Luz',2

(Physical Education Professional)

João Valente-dos-Santos ${ }^{2,3}$

(Physical Education Professional)

João Pedro Duarte²

(Physical Education Professional)

André Filipe Teixeira e Seabra ${ }^{4}$

(Physical Education Professional)

Cristina Padez ${ }^{5}$

(Anthropologist)

Manuel João Coelho e Silva²

(Physical Education Professional)
\end{abstract}

1. Universidade Federal de Alagoas, Laboratório de Cineantropometria, Atividade Física e Promoção da Saúde (LACAPS), Arapiraca,

Alagoas, AL, Brazil.

2. Universidade de Coimbra, CIDAF (uid/dtp/04213/2016),

Coimbra, Portugal.

3. Universidade Lusófona

Humanidades e Tecnologia Lisboa, Lisboa, Portugal.

4. Universidade do Porto (CIAFEL), Porto, Portugal.

5. Universidade de Coimbra (CIAS),

Coimbra, Portugal.

\section{Correspondence:}

Rua Vale das Flores, 43, 1B, 3030-486, Coimbra, Portugal. leonardoluz.ufal@gmail.com

\section{ABSTRACT}

Introduction: Biological maturation has been related to the level of physical activity and motor competence of children. Objectives: This study aimed to: 1) analyze the association between biological maturation and performance in muscular strength tests and 2) examine whether the relationship between maturation and performance in physical tests is mediated by anthropometric variables. Method: The sample was composed of 71 eight-year-old Brazilian girls. Anthropometry considered stature, body mass, waist circumference, estimated fat mass and fat-free mass. Biological maturation was assessed based on the percentage of predicted adult stature. The physical tests consisted of 2-kg medicine ball throw, handgrip strength, sit-ups and standing long jump. Pearson's correlation test was conducted between the study variables and the last stage consisted of a causal mediation analysis. Results: Biological maturation was significantly associated with the 2 -kg medicine ball throw ( $r=0.52)$ and handgrip strength ( $r=0.42)$ tests. In the $2-\mathrm{kg}$ medicine ball throw, the relationship with maturation was mediated by body mass (total mediation, Sobel's Test $=2.214, p<0.05$ ) and by estimated lean mass (total mediation; Sobel's Test $=3.146, p<0.001$ ). In the handgrip strength test, body mass was the only mediating variable (total mediation; Sobel's Test $=2.251, p<0.05$ ). Conclusions: Advanced maturational status appears to contribute to the performance of prepubescent girls in muscular strength tests in which there is no translocation of total or partial body mass. It is recommended that studies be conducted in other age groups. Level of Evidence III; Study of nonconsecutive patients; without consistently applied reference "gold" standard.

Keywords: Motor skills; Anthropometry; Exercise.

\section{RESUMO}

Introdução: A maturação biológica tem sido relacionada com o nível de atividades físicas e a competência motora das crianças. Objetivos: O presente estudo teve como objetivos: 1) analisar a associação da maturação biológica com o desempenho em testes de força muscular e 2) examinar se a relação entre o estado maturacional e o desempenho nos testes físicos é mediada por variáveis antropométricas. Método: A amostra foi composta por 71 meninas brasileiras com oito anos de idade. A antropometria considerou estatura, massa corporal, perímetro da cintura, estimativas de massa gorda e massa magra. A maturação biológica foi avaliada através do percentual da estatura matura predita. Os testes físicos aplicados consistiam em lançamento-2kg, preensão manual, abdominais e salto horizontal. A correlação de Pearson foi realizada entre as variáveis do estudo e, por último, a análise de mediação causal. Resultados: A maturação biológica associou-se significativamente à prova de lançamento-2kg $(r=0,52)$ e preensão manual $(r=0,42)$. No teste de lançamento- $2 \mathrm{~kg}$, a relação com o estado maturacional foi mediada pela massa corporal (mediação total; Teste de Sobel=2,214, $p<0,05$ ) e pela estimativa de massa magra (mediação total; Teste de Sobel=3,146, p<0,001). Já no teste de preensão manual, a massa corporal foi a única variável mediadora (mediação total; Teste de Sobel=2,251, p<0,05). Conclusões: O estado maturacional avançado parece contribuir com o desempenho de meninas pré-púberes em testes de força muscular em que não há translocação da massa corporal total ou parcial. Recomenda-se que sejam realizados estudos em outras faixas etárias. Nível de Evidência Ill; Estudo de pacientes não consecutivos; sem padrão de referência "ouro" aplicado uniformemente.

\section{Descritores: Destreza motora; Antropometria; Exercício.}

\section{RESUMEN}

Introducción: La maduración biológica ha sido relacionada con el nivel de actividades físicas y la competencia motora de los niños. Objetivos: El presente estudio tuvo como objetivos: 1) analizar la asociación de la maduración biológica con el desempeño en tests de fuerza muscular y 2) examinar si la relación entre el estado de maduración y el desempeño en los tests físicos es mediada por variables antropométricas. Métodos: La muestra fue compuesta por 71 niñas brasileñas con ocho años de edad. La antropometría consideró estatura, masa corporal, perímetro de cintura, estimaciones de masa grasa y masa magra. La maduración biológica fue evaluada a través del porcentual de la estatura madura predicha. Los tests físicos aplicados consistían en lanzamiento-2kg, prensión manual, abdominales y salto horizontal. La correlación de Pearson fue realizada entre las variables del estudio y, por último, el análisis de mediación causal. Resultados: La maduración biológica se asoció significativamente al test de lanzamiento-2kg $(r=0,52)$ y prensión manual $(r=0,42)$. En el test de lanzamiento-2kg, la relación con el estado de maduración fue 
mediada por la masa corporal (mediación total, Test de Sobel =2,214, $p<0,05$ ) y por la estimativa de masa magra (mediación total, Test de Sobel $=3,146, P<0,001$ ). Ya en el test de prensión manual, la masa corporal fue la única variable mediadora (mediación total, Test de Sobel =2,251,p<0,05). Conclusiones: El estado de maduración avanzado parece contribuir con el desempeño de niñas prepúberes en tests de fuerza muscular en los que no hay translocación de la masa corporal total o parcial. Se recomienda que sean realizados estudios en otros grupos de edad. Nivel de Evidencia III; Estudio de pacientes no consecutivos; sin estándar de referencia "oro" aplicado uniformemente.

Descriptores: Destreza motora; Antropometría; Ejercicio.

\section{INTRODUCTION}

Motor competence is a global term used to describe the human movement proficiency status. ${ }^{1}$ Stodden et al. ${ }^{2}$ proposed that physical activity is important in the development of motor competence in early childhood. Some authors assert that physical activity during the first years of life contributes to the development of a child's neuromotor function, which, in turn, promotes the development of his or her motor competence. ${ }^{2,3}$ However, better motor competence becomes a predictor of participation in physical activities and of healthy weight status with

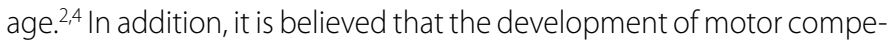
tence in childhood may influence motivation and adherence to physical activity in youths, ${ }^{3}$ besides greater involvement in games and sports. ${ }^{5}$

However, despite the concordance among studies concerning the association between motor competence and numerous variables related to the health of the pediatric population, ${ }^{1,6}$ the ecological examination of these variables is clearly difficult, as there are many factors related to the individual, his or her life course and the surrounding environment that were not taken into account by the literature consulted and appear to affect the associations studied. ${ }^{7,8}$ Moreover, despite the plentiful evidence presented on the subject, it can be noted that there is no elucidatory description of the multiple factors that determine the strong variability in the levels of motor competence of children and youths.

In this context, maturation has been related to physical activity ${ }^{7,9}$ and the motor competence of young subjects. ${ }^{7,10}$ The first studies to analyze the associations of motor performance tests with biological maturation, chronological age, stature and body mass in six- to eight-year-old children were limited to partial correlations, which were classified, at best, as low to moderate. ${ }^{11,12}$ Subsequent studies, using bone age as a maturity indicator, made use of linear regression for data analysis. Skeletal age, either separately or in interaction with body size, explained part of the variances ( 4\% to 30\%) in several physical performance tests in children and adolescents. ${ }^{10,13}$ There appears to be a consensus in the literature regarding the effect of maturation on its own, or predominantly in interaction with anthropometric measurements related to body size, on performance in physical tests of children. However, the evidence is restricted to body mass and stature measurements, and does not employ data analysis techniques that would make it possible to clarify the nature of the contribution of body size to the association of maturation with motor performance.

In view of the above, this study aimed to: 1) analyze the association between biological maturation and performance in muscle strength tests of prepubescent girls and 2) investigate whether the relationship between maturation and physical performance is mediated by anthropometric variables.

\section{MATERIALS AND METHODS}

This is a descriptive cross-sectional study that was planned and conducted in compliance with international standards governing human experimentation (1975 Declaration of Helsinki), duly approved by the
Institutional Review Board of the Universidade Federal de Alagoas, registered under CAAE (Certificado de Apresentação para Apreciação Ética) [Ethics Evaluation Submission Certificate] opinion no. 09200413.5.0000.5013. Data were collected at four schools in Arapiraca/Alagoas, Brazil. Participants were selected through non-probability sampling for accessibility. The consent forms were given to all the female children within the age group of interest of the study, and to their respective parents/guardians.

The sample consisted of 71 female schoolchildren, aged between 8 and 8.99 years, representing about $85 \%$ of the number of eligible children. Failure to deliver the consent form, absence on the day of the data collection, or any physical inability to perform the battery of physical tests were considered study exclusion criteria.

The anthropometric variables measured were stature, body mass, waist circumference and skinfolds, all performed at school during the same period. Stature $(0.1 \mathrm{~cm})$ was measured with a portable stadiometer (Sanny Caprice, São Paulo, Brazil). Body mass (0.1kg) was measured using a digital scale (Techline, São Paulo, Brazil). Participants showed up for the measurements barefoot and wearing light clothing. Waist circumference $(0.1 \mathrm{~cm})$ was measured at the midpoint between the last rib and the iliac crest, at minimum respiration rate, using a steel anthropometric measuring tape (Sanny Medical Starrett, São Paulo, Brazil). The subscapular, triceps and leg skinfolds ( $1 \mathrm{~mm}$ ) were measured with a Lange skinfold caliper (Beta Technology, Santa Cruz, California, USA). The procedures used were based on the instructions produced by Lohman et al. ${ }^{14}$ In addition to the simple anthropometric measurements, body mass index (BMI) and fat percentage ${ }^{15}$ were calculated and used to divide body mass into fat and fat-free mass estimates. The technical error of measurement and the reliability coefficient of the anthropometric measurements were obtained by test-retest, with a one week interval, in a group of 19 children. The values were, respectively: stature $(0.6 \mathrm{~cm}, 0.98)$, body mass $(0.6 \mathrm{~kg}, 0.99)$, waist circumference $(1.6 \mathrm{~cm}, 0.93)$ and skinfolds (1.0-1.4 mm, 0.94-0.98).

Maturation was evaluated using the predicted adult stature (PAS) method. The percentage of predicted adult stature (\%PAS) achieved at a given age by the Khamis and Roche ${ }^{16}$ method is characterized as being non-invasive and offering results in a continuous format. In this study the parents' statures were self-reported. The measurement is moderately associated with bone age, considered a biological maturation benchmark indicator. ${ }^{17}$

Muscle strength was assessed using a number of tests from the EUROFIT battery, ${ }^{18}$ namely: horizontal thrust and handgrip strength. 60-s (second) sit-ups ${ }^{19}$ and $2 \mathrm{~kg}$-medicine ball throw, performed with both arms simultaneously, ${ }^{19}$ were also added to the battery. The intraclass correlation coefficients for each test from the battery are as follows: 0.79 (2kg-medicine ball throw); 0.87 (handgrip strength); 0.84 (60-s sit-ups) and 0.78 (horizontal thrust).

\section{Statistical analysis}

The descriptive analysis was performed with measures of central tendency and dispersion. This was followed by the Kolmogorov-Smirnov normality test, with logarithmic transformation of the non-normal 
variables. In addition, Pearson's correlation test was conducted between the anthropometric variables, the maturation and the results of each physical test. Linear regression models were adjusted based on the procedures described by Baron and Kenny. ${ }^{20}$ The criteria adopted to establish a mediation were: 1) the independent variable (maturation) should be significantly related to the dependent variable (performance in the strength tests); 2) the independent variable should be significantly related to the mediator variable (anthropometric variables); 3 ) the mediator variable should be significantly related to the dependent variable; and 4) the association between the independent variable and the dependent variable should be diminished when the mediator variable is included in the regression model. Finally, the mediation was confirmed in accordance with Sobel. ${ }^{21}$ Further details on the Baron and Kenny and Sobel procedures can be found in Luz et al. ${ }^{22}$ Significance of $p<0.05$ was adopted in the analyses. IBM SPSS 22.0 software (SPSS, Inc., Chicago, IL) was used in the study.

\section{RESULTS}

Table 1 shows the descriptive results of the sample. The mean age of the girls evaluated was 8.45 years. The mean PAS is $163.3 \mathrm{~cm}$ and the \%PAS values range from $75.3 \%$ to $85.2 \%$.

Table 1. General characteristics of the overall sample $(n=71)$.

\begin{tabular}{|c|c|c|c|c|c|}
\hline \multirow{2}{*}{ Variables } & \multicolumn{2}{|c|}{ Amplitude } & \multicolumn{2}{|r|}{ Mean } & \multirow{2}{*}{$\begin{array}{l}\text { Standard } \\
\text { deviation }\end{array}$} \\
\hline & Minimum & Maximum & Value & $(95 \% \mathrm{Cl})$ & \\
\hline $\begin{array}{c}\text { Chronological age } \\
\text { (years) }\end{array}$ & 8.00 & 8.99 & 8.45 & (8.38 to 8.52 ) & 0.29 \\
\hline PAS (cm) & 147.7 & 178.0 & 163.3 & $\begin{array}{c}\text { (161.9 to } \\
164.8)\end{array}$ & 6.1 \\
\hline PAS percentage (PAS\%) & 75.3 & 85.2 & 79.9 & (79.4 to 80.4) & 2.2 \\
\hline Stature $(\mathrm{cm})$ & 119.0 & 143.4 & 130.5 & $\begin{array}{c}\text { (129.1 to } \\
131.9)\end{array}$ & 5.8 \\
\hline Body mass (kg) & 20.7 & 43.5 & 29.8 & (28.4 to 31.2$)$ & 5.7 \\
\hline $\begin{array}{c}\text { Body mass index } \\
\left(\mathrm{kg} \cdot \mathrm{m}^{-2}\right)\end{array}$ & 13.1 & 26.5 & 17.4 & (16.7 to 18.1$)$ & 2.9 \\
\hline $\begin{array}{l}\text { Waist circumference } \\
(\mathrm{cm})\end{array}$ & 45.5 & 75.8 & 58.9 & (57.3 to 60.4 ) & 6.5 \\
\hline $\begin{array}{c}\text { Body fat percentage } \\
(\%)\end{array}$ & 18.6 & 37.0 & 27.3 & (26.1 to 28.5$)$ & 4.9 \\
\hline Fat mass (kg) & 4.0 & 15.1 & 8.3 & (7.7 to 9.0$)$ & 2.9 \\
\hline Fat-free mass (kg) & 15.7 & 29.1 & 21.4 & (20.7 to 22.2) & 3.2 \\
\hline $\begin{array}{l}2 \mathrm{~kg} \text {-medicine ball } \\
\text { throw }(\mathrm{cm})\end{array}$ & 113.0 & 246.2 & 175.1 & $\begin{array}{c}\text { (168.0 to } \\
182.2)\end{array}$ & 30.1 \\
\hline Handgrip (kgf) & 5.5 & 23.0 & 12.0 & (11.2 to 12.8$)$ & 3.2 \\
\hline Sit-ups (repetitions) & 0 & 34 & 15.5 & (13.5 to 17.5$)$ & 8.6 \\
\hline $\begin{array}{l}\text { Standing long jump } \\
(\mathrm{cm})\end{array}$ & 32.0 & 197.9 & 82.4 & (76.6 to 88.1 ) & 24.4 \\
\hline
\end{tabular}

95\%Cl (95\% Confidence interval); PAS (Predicted adult stature).
Table 2 shows the correlation coefficients between the anthropometric variables, the \%PAS and performance in each strength test. Stature $(r=0.55)$, body mass $(r=0.89)$, waist circumference $(r=0.79)$, estimated body fat mass $(r=0.81)$ and estimated fat-free mass $(r=0.88)$ were significantly associated with the \%PAS. The \%PAS was significantly associated with the $2 \mathrm{~kg}$-medicine ball throw $(r=0.52)$ and handgrip strength $(r=0.42)$ tests. The $2 \mathrm{~kg}$-medicine ball throw and handgrip strength tests had a significant positive relationship with all the anthropometric variables.

Figure 1 shows the total mediation of body mass (Sobel $=2.214$, $p<0.05$ ) and of estimated fat-free mass (Sobel $=3.146, p<0.001$ ) in the positive effect of maturation on the $2 \mathrm{~kg}$-medicine ball throw.

Figure 2 shows the results of the total mediation that body mass presents in the positive effect of maturation on performance of the handgrip strength test (Sobel=2.251, $\mathrm{p}<0.05$ ).

\section{DISCUSSION}

This study provided evidence that maturation is positively related with all the anthropometric variables studied in eight-year-old girls. Maturation was also positively associated with the $2 \mathrm{~kg}$-medicine ball throw and handgrip strength tests, whose effect was mediated by body mass and estimated fat-free mass. In other words, in the muscle strength tests carried out with the upper limbs, in which body mass was not totally or partially displaced, individuals with a more advanced maturation had the best results.

The relationship between biological maturation and the level of physical activity 7,9 and motor performance ${ }^{7,10}$ are aspects reported in the literature. Katzmarzyk et al. ${ }^{10}$ stated that the effects of biological maturation on children are expressed mainly through body size, and that maturation had the greatest influence on children's physical performance. Furthermore, the consequences of advanced maturation are initially concentrated in biological changes, many of which may influence performance and involvement in physical activity through changes in functional capacity. ${ }^{10,23}$ In addition, changes related to body size, physique and secondary sexual characteristics may influence the nature of interpersonal relationships, which may be relevant to participation in various forms of physical activity, ${ }^{24}$ and may also have an impact on aspects related to motor competence in young people.

Malina et al. ${ }^{7}$ stated that morphological characteristics influence motor performance more significantly in younger children than in older children. In this context, Kondric et al., ${ }^{25}$ in a study of 4- to 6-year-old children, mentioned that body mass and stature are considered the most significant predictors of motor competence in linear and nonlinear regression models. According to the authors, ${ }^{25}$ the results found are based on the fact that younger children (e.g.: preschool-age children) have not have time to develop motor competence independently of the morphological characteristics that directly influence motor performance. Recently, in a systematic review study,

Table 2. Pearson's correlation coefficients (and their respective 95\% confidence intervals) between anthropometric variables, maturation and performance in muscle strength tests $(n=71)$.

\begin{tabular}{c|c|c|c|c|c}
\hline \multirow{2}{*}{$\begin{array}{c}\text { Anthropometric } \\
\text { variables }\end{array}$} & \multirow{2}{*}{ PAS\% } & \multicolumn{4}{|c}{ Muscle strength tests } \\
\cline { 3 - 6 } & 2kg-medicine ball throw & Handgrip & Sit-ups & Standing long jump \\
\hline Stature & $0.55(0.36-0.69)$ & $0.43(0.22-0.60)$ & $0.40(0.18-0.58)$ & $0.17(-0.07-0.39)$ & $-0.01(-0.24-0.22)$ \\
\hline Body mass & $0.89(0.83-0.93)$ & $0.57(0.39-0.71)$ & $0.49(0.29-0.65)$ & $-0.14(-0.36-0.10)$ & $-0.19(-0.40-0.04)$ \\
\hline Waist circumference & $0.79(0.68-0.86)$ & $0.48(0.28-0.64)$ & $0.39(0.17-0.57)$ & $-0.16(-0.38-0.08)$ & $-0.19(-0.40-0.04)$ \\
\hline Fat mass & $0.81(0.71-0.88)$ & $0.46(0.25-0.63)$ & $0.46(0.25-0.63)$ & $-0.18(-0.40-0.06)$ & $-0.16(-0.38-0.08)$ \\
\hline Fat-free mass & $0.88(0.81-0.92)$ & $0.61(0.44-0.74)$ & $0.46(0.25-0.63)$ & $-0.09(-0.32-0.15)$ & $-0.20(-0.41-0.03)$ \\
\hline PAS\% & - & $0.52(0.33-0.67)$ & $0.42(0.21-0.59)$ & $-0.09(-0.32-0.15)$ & $-0.08(-0.31-0.16)$ \\
\hline
\end{tabular}

PAS\% (Predicted adult stature percentage). 


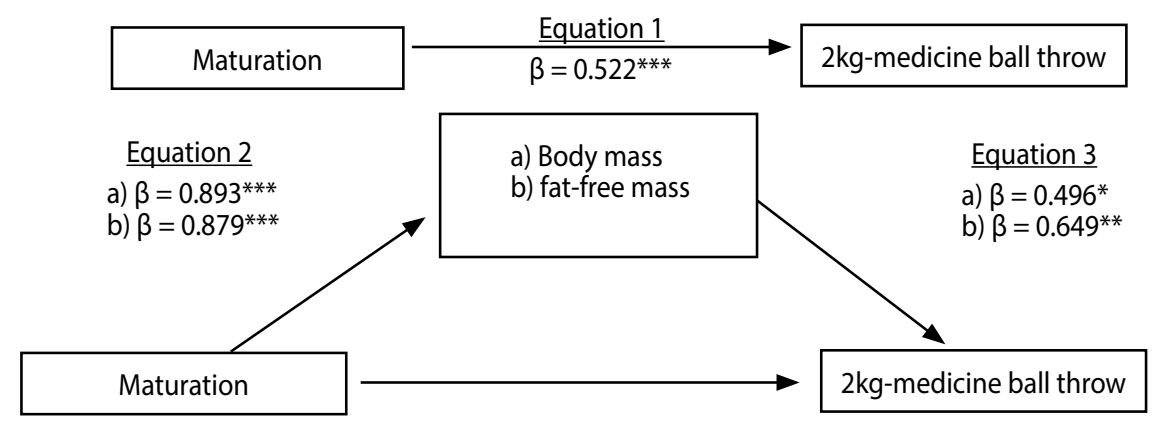

Equation 3

a) $\beta=0.079$

b) $\beta=-0.048$

Sobel Test

a) $2.214^{*}$

b) $3.146^{* * *}$

Figure 1. Model of body mass and estimated fat-free mass mediation in the effect of maturation on the performance of the $2 \mathrm{~kg}$-medicine ball throw test in girls.

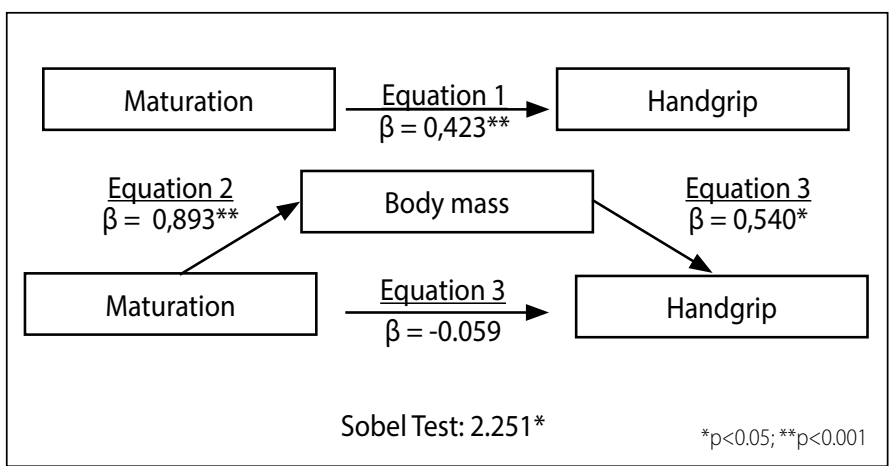

Figure 2. Model of body mass mediation in the effect of maturation on the performance of the handgrip strength test in girls.

Barnett et al. ${ }^{26}$ stated that motor development is influenced mainly by biological maturation in early childhood, while it is influenced mainly by physical activity and the opportunity to engage in such activities after this period. Evidence from the literature suggests that in prepubescent children, interindividual differences in performance in motor competence tests can be partly explained by maturation, and that this relationship tends to increase when in interaction with body size measurements. 10,13,27 The results of this study corroborate this evidence and add value, not only because they reinforce the association between maturation and performance in motor tests of prepubescent children, but also because they identify the mediating role of anthropometric characteristics, specifically of body mass and estimated fat-free mass.

Evidence from the literature suggests that interindividual differences in maturation status may positively or negatively affect performance in motor competence tests. ${ }^{10,13,27}$ Furthermore, the nature of the association may vary according to the age and sex of the individual as well as the characteristics of the task. In this study, the sample was composed only of girls of the same chronological age, which allowed a performance analysis focused more closely on the characteristics of the task. Katzmarzyk et al. ${ }^{10}$ suggest that while maturation of the neuromuscular system may contribute positively to the development of motor skills, maturity-related changes with regards to body size and body composition may adversely affect performance, particularly in activities where body mass has to be displaced. In this context, females are apparently at a disadvantage as they are more prone to greater absolute and relative gain of body fat mass during puberty. ${ }^{13,27}$ This may be the reason why Beunen et al. ${ }^{13}$ reported an inverse association between bone age and performance in various muscle strength tests, such as bar pulls, leg elevations and sit-ups. It is worth mentioning that the tests selected by Beunen et al. ${ }^{13}$ are characterized by mobilization of total or partial body mass.

This study had some limitations: the data were cross-sectional and correlational, which does not allow declarations of causality; in addition, we used a somatic indicator of maturation, the percentage of the predicted adult stature reached at the time of the study, with the parents' stature values obtained by self-reporting, similar to a previous study. ${ }^{27}$

\section{CONCLUSIONS}

Based on the evidence, the results emphasize the need to focus attention on knowledge of the maturation of individuals, since its effect appears to partly explain the interindividual differences found in same-sex subjects in some motor competence evaluation tests. It is recommended that maturation be evaluated in future studies using the bone age method, that the sample potentially contain girls from other age groups, and that similar approaches be adopted with a sample formed exclusively by male subjects.

\section{ACKNOWLEDGMENTS}

Support of the Coordenação de Aperfeiçoamento de Pessoal de Nível Superior (Coordination of Improvement of Higher Education Personnel - (APES) in the form of a grant, process number: 1617/13-3. Fundação para a Ciência e a Tecnologia (Science and Technology Foundation) [uid/dtp/04213/2016; SFRH/BD/101083/2014; SFRH/ BPD/100470/2014].

All authors declare no potential conflict of interest related to this article. 
AUTHORS' CONTRIBUTIONS: Each author made significant individual contributions to this manuscript. LGOL (0000-0003-1436-1125)*: data collection, writing, statistical analysis and revision; TDDL (0000-0002-7508-9252)*: data collection and writing; JVS (0000-0003-0980-0269)* and JPD (0000-0002-7536-9780**: writing and revision of the statistical analysis; AFTS (0000-0002-6788-4555)*: writing and revision of the entire intellectual concept; CP (0000-0002-1967-3497)*: drafting of the research project and revision; MJCS (0000-0003-4512-7331)* drafting of the entire research project and revision of the entire intellectual concept. All authors contributed to the intellectual concept of the study and approved the final version of the manuscript. *ORCID (Open Researcher and Contributor ID).

\section{REFERENCES}

1. Robinson LE, Stodden DF, Barnett LM, Lopes VP, Logan SW, Rodrigues LP, et al. Motor competence and its effect on positive developmental trajectories of health. Sports Med. 2015;45(9):1273-84.

2. Stodden DF, Goodway JD, Langendorfer SJ, Roberton MA, Rudisill ME, Garcia C, et al. A developmental perspective on the role of motor skill competence in physical activity: an emergent relationship. Quest. 2008;60(2):290-306

3. Okely AD, Booth ML, Patterson JW. Relationship of physical activity to fundamental movement skills among adolescents. Med Sci Sports Exerc. 2001;33(11):1899-904.

4. Lopes VP, Rodrigues LP, Maia JA, Malina RM. Motor coordination as predictor of physical activity in childhood. Scand J Med Sci Sports. 2011;21(5):663-9.

5. Graham DJ, Sirard JR, Neumark-Sztainer D. Adolescents' attitudes toward sports, exercise, and fitness predict physical activity 5 and 10 years later. Prev Med. 2011;52(2):130-2.

6. Cairney J, Hay J, Veldhuizen S, Faught B. Comparison of $\mathrm{VO}_{2}$ maximum obtained from $20 \mathrm{~m}$ shuttle run and cycle ergometer in children with and without developmental coordination disorder. Res Dev Disabil. 2010;31(6):1332-9.

7. Malina RM, Bouchard C, Bar-Or O. Growth, maturation, and physical activity. 2nd.ed. Champaign, IL: Human Kinetics; 2004

8. Saraiva JP, Rodrigues LP. Relações entre a actividade física, aptidão física, morfológica e coordenativa na infância e adolescência. Motri. 2010;6(4):35-45.

9. Bacil ED, Mazzardo Júnior O, Rech CR, Legnani RF, Campos W. Physical activity and biological maturation: a systematic review. Rev Paul Pediatr, 2015;33(1):114-21.

10. Katzmarzyk PT, Malina RM., Beunen GP. The contribution of biological maturation to the strength and motor fitness of children. Ann Hum Biol. 1997;24(6):493-505.

11. Seils LG. The relationship between measures of physical growth and gross motor performance of primary-grade school children. Res Q. 1951;22(2):244-60.

12. Rarick GL, Oyster N. Physical maturity, muscular strength, and motor performance of young school-age boys. Res Q. 1964;35:523-31

13. Beunen GP, Malina RM, Lefevre J, Claessens AL, Renson R, Kanden Eynde B, et al. Skeletal maturation somatic growth and physical fitness in girls 6-16 years of age. Int J Sports Med. 1997;18(6):413-9.

14. Lohman TG, Roche AF, Martorell R. Anthropometric standardization reference manual. Champaign, IL: Human Kinetics; 1988
15. Slaughter MH, Lohman TG, Boileau RA, Horswill CA, Stillman RJ, Van Loan MD, et al. Skinfold equations for estimation of body fatness in children and youth. Hum Biol. 1988;60(5):709-23.

16. Khamis HJ, Roche AF. Predicting adult stature without using skeletal age: the Khamis-Roche method Pediatrics. 1994:94(4 Pt 1):504-7.

17. Malina RM, Dompier TP, Powell JW, Barron MJ, Moore MT. Validation of a noninvasive maturity estimate relative to skeletal age in youth football players. Clin J Sport Med. 2007;17(5):362-8.

18. Committee for the Development of Sports. EUROFIT: Handbook for the Eurofit test of physical fitness Rome, Italy: Council of Europe; 1998

19. Sobral F, Coelho e Silva MJ. Açores 1999: estatísticas e normas de crescimento e aptidão física. Coimbra: Universidade de Coimbra; 2001.

20. Baron RM, Kenny DA. The moderator-mediator variable distinction in social psychological research: conceptual, strategic, and statistical considerations. J Pers Soc Psychol. 1986;51(6):1173-82.

21. Sobel ME. Asymptotic confidence intervals for indirect effects in structural equation models. In: Leinhardt S, editor. Sociological methodology. Washington: American Sociological Association;1982. p. 290-312.

22. Luz LG, Seabra A, Padez C, Duarte JP, Rebelo-Gonçalves R, Valente-dos-Santos J, et al. Waist circumference as a mediator of biological maturation effect on the motor coordination in children. Rev Paul Pediatr. 2016;34(3):352-8.

23. Lefevre J, Beunen G, Steens G, Claessens A, Renson R. Motor performance during adolescence and age thirty as related to age at peak height velocity. Ann Hum Biol. 1990;17(5):423-35.

24. Sherar LB, Cumming SP, Eisenmann JC, Baxter-Jones ADG, Malina RM. Adolescent biological maturity and physical activity: biology meets behavior. Pediatr Exerc Sci. 2010;22(3):332-49.

25. Kondric M, Trajkovski B, Strbad M, Foretić N, Zenić N. Anthropometric influence on physical fitness among preschool children: gender-specific linear and curvilinear regression models. Coll Antropol 2013;37(4):1245-52.

26. Barnett LM, Lai SK, Veldman SL, Hardy LL, Cliff DP, Morgan PJ, et al. Correlates of gross motor competence in children and adolescents: a systematic review and meta-analysis. Sports Med. 2016:46(11):1663-88

27. Drenowatz C, Wartha O, Klenk J, Brandstetter S, Wabitsch M, Steinacker J. Differences in health behavior, physical fitness, and cardiovascular risk in early, average, and late mature children. Pediatr Exerc Sci. 2013;25(1):69-83. 